\title{
The implementation of problem-based learning (pbl) model to improve creativity and self-efficacy of field dependent and field independent students
}

\author{
Farrah Maulidia ${ }^{1 *}$, Saminan ${ }^{1}$, and Zainal Abidin ${ }^{2}$ \\ ${ }^{1}$ Department of Mathematics Education, Universitas Syiah Kuala, Banda Aceh, Indonesia, 23111 \\ ${ }^{2}$ Department of Mathematics Education, Universitas Islam Negeri Ar-Raniry, Banda Aceh, Indonesia, 23111 \\ * Corresponding author: farrahmaulidia@gmail.com | Phone Number: +6285277437249
}

\section{ARTICLE HISTORY}

Received : 19 March 2020

Revised : 26 March 2020

Accepted : 8 April 2020

\section{KEYWORDS}

Action research; Mathematics; Problem based learning; Self-efficacy;

\begin{abstract}
Students' creativity and self-efficacy in solving mathematical problems remain low. Students with Field Dependent (FD) and Field Independent (FI)cognitive styles have different creativity and self-efficacy. One learning model that is believed to increase students' creativity and self-efficacy is Problem Based Learning (PBL) model. This study aimed to increase the creativity and self-efficacy of FD and FI students through the application of PBL model. This research is an experimental study with pre-test and post-test control group design. The population of this research was grade VIII students in State Islamic School (MTsN) 1 Banda Aceh, while the sample consisted of two classes out of 11 classes. The sampling technique used random sampling with one experimental class and one control class. Data collection was carried out by using two instruments; a paper-test to measure students' creativity and a questionnaire to measure students' self-efficacy. The grouping of FD and FI students was based on the results of the Group Embedded Figure Test (GEFT). Furthermore, a paired t-test was conducted to obtain an increase in students' creativity and self-efficacy. At the same time, a correlation test was performed to see the relationship between creativity and the self-efficacy of students. The results of the study revealed that the increase of FD and FI students' creativity who were taught by the PBL model was better than students taught by conventional methods. The results also reported that the increase of FD and FI students' selfefficacy who were taught with the PBL model was better than the students who were taught with conventional methods. In addition, there was a significant relationship between FI and FD students' creativity and self-efficacy.
\end{abstract}

This is an open access article under the CC-BY-SA license.

\section{INTRODUCTION}

Creativity is a dynamic process within a person that can produce several strategies in solving a given problem. Creativity also allows someone to modify something (Asri and Warsito, 2015). Mathematical creativity is a very valuable thing that students should have, so students are expected to foster mathematical creativity by solving various forms of mathematical problems (Akgul \& Kahveci, 2016). Students who have high creativity can solve problems better, more unique and faster than students who have a lack of creativity. Olympic students can solve problems faster and more unique than students in general. This fact shows that Olympic students have excellent creativity, but it is expected that not only Olympic students but also all students who must have creativity in solving mathematical problems.

Moreover, another thing that is important to be considered own by students is self-efficacy. Students' self-efficacy is a determining factor for students to be a success at school. It happens because high self-efficacy students believe that they are able to master the tasks and regulate their learning (Anggara, Muri \& Marjohan, 2016). Mathematics learning also requires high self-efficacy, which aims to create students' confidence in solving mathematical problems. Self-efficacy is an important factor as a support for students to get the good and satisfying academic achievement (Caprara, Vecchione, Alessandri, Gerbino \& Barbaranelli, 2011).

However, the fact is that Indonesian students have low ability to solve mathematical problems. It can be seen from the results of national mathematics exams of elementary to secondary education students. Besides, based on the Trends International Mathematics and Science Study(TIMSS) and the Program for International Student Assessment(PISA) results, it is also known that Indonesian students get a low score of 386 in TIMSS, and in the 69th rank of 76 countries in PISA (Mullis, 2012; OECD, 2013).

The law rank of Indonesian students is because of the students are lack of training in solving contextual questions, the questions which demand students' reasoning, argumentation and creativity, whereas they are characteristic of TIMSS questions. Also, the biggest problem that causes low mathematical achievement is the presentation of mathematics topic as a finished product, ready to use, abstract and taught mechanically (Sembiring, Hadi \& Dolk, 2008). Another cause of the lack of students' creativity development in solving mathematical problems is self-efficacy. The lack of students' 
self-efficacy in solving a mathematical problem can cause the law of creativity.

The previous problem is related to research conducted by Noer (2011). He stated that the lack of students' creativity in solving mathematical problems is due to the learning occurred in the classroom, where students are immediately given definitions and examples of routine problems without being linked to daily life problems. Several things can increase student creativity in solving mathematical problems; one of them is a learning model that is implemented during the teaching and learning process. One model that can enhance students' creativity and self-efficacy in solving mathematical problems is the Problem Based Learning (PBL) learning model.

A study by Cahyaningsih and Ghufron (2016) showed that there is a positive influence on the application of PBL learning model to students' creative character in mathematics learning. Besides the learning model, teachers can deliver learning by knowing the cognitive styles of each student. One cognitive style that can show a person's characteristics in responding, processing, memorising, thinking, and using the information to respond to an assignment is the cognitive style of Field Dependent (FD) and Field Independent (FI). Kogan and Slavin (2008) revealed that one of the individual differences in cognitive style is in terms of one's dependence on other things (FD)and one's independence to other things (FI).

The research questions of this study are:

1) Is the increase of FD and FI students' creativity for who learnt with PBL model better than students who learnt with conventional models?

2) Is the increase of FD and FI students' self-efficacy for who learnt with the PBL model better than students who learnt with conventional models?

3) Is there a significant relationship between students' creativity and self-efficacy interms of the FD and FI cognitive styles?

\section{RESEARCH METHOD}

This study used a quantitative research method which aimed to test a treatment, namely the application of the PBL model. The type of this research was true experimental design with the research design used was pre-test post-test control group design. The experimental design was conducted to determine the level of creativity of FD and FI students based on Creswell (2013).

Students' mathematical creativity in both groups could be measured after post-test. Post-test was given after the learning process was completed to determine the effect of applying PBL models to students' mathematical creativity. However, to measure the difference between students' self-efficacy in both groups, a self-efficacy questionnaire was administered at the end of learning.

This research was conducted at Banda Aceh State Islamic School (MTsN Model) from February 19 to March 21, 2018. The population in this study were all grade 8 MTsN Model students in the even semester in the $2017 / 2018$ school year, while the sample was two classes of grade 8 Banda Aceh MTsN Model students. There was random sampling, and after the sample was randomly selected, a GEFT test was performed to classify the cognitive styles of students, namely FD and FI. The selection of the experimental and control classes was also based on the results of the GEFT test.

The variables were grouped into two types, namely independent variables and dependent variables. The independent variables were mathematics learning with PBL models and FD and FI cognitive styles, while the dependent variables were students' mathematical creativity and selfefficacy. This research used two types of instruments, namely test instruments and non-test instruments. The test instrument consisted of students' mathematical creativity tests which were in the form of essays and GEFT tests for cognitive grouping styles. The non-test instrument was an instrument to measure students' self-efficacy in the form of a questionnaire. Hypothesis testing was conducted by using Independent t-test for pre-test and post-test data of students' mathematical creativity with significant level $\alpha=0.05$ and calculated by the formula:

$$
t_{\text {count }}=\frac{\bar{x}_{1}-\bar{x}_{2}}{S_{\text {total }} \sqrt{\frac{n_{1}+n_{2}}{n_{1}-n_{2}}}}
$$

The students' self-efficacy data were analysed using the Smantig scale and to discover the correlation between students' creativity and self-efficacy, a two-way correlation test was conducted. The formula used to discover the correlation between creativity and self- efficacy was the Pearson Correlation Coefficient correlation formula as follow (Arikunto, 2010):

$$
r_{x y}=\frac{n \sum X Y-\sum X \sum Y}{\sqrt{\left(n \sum X^{2}-\left(\sum X\right)^{2}\right)\left(n \sum Y^{2}-\left(\sum Y\right)^{2}\right)}}
$$

Annotation:

$\mathrm{r}_{\mathrm{xy}}=$ correlation coefficient

$\mathrm{X}=$ value of creativity

$\mathrm{Y}=$ value of self-efficacy

$\mathrm{n} \quad$ the number of students

The Research Hypotheses Are:

Hypothesis 1: Creativity and Self-Efficacy of FD students

$\mathrm{H}_{0}: \mu_{1}=\mu_{2}$ (There is no difference between the creativity and self-efficacy of FD students in the experimental and the control group)

$\mathrm{H}_{1}: \mu_{1}>\mu_{2}$ (Creativity and self-efficacy of FD students in the experimental group are better than in the control group)

Hypothesis 2: Creativity and Self-Efficacy of FI students

$\mathrm{H}_{0}: \mu_{1}=\mu_{2}$ (There is no difference between the creativity and self-efficacy of the FI students in the experimental group and the control group)

$\mathrm{H}_{1}: \quad \mu_{1}>\mu_{2}$ (Creativity and self-efficacy of the FI students in the experimental group are better than the control group)

Hypothesis 3: The relationship between creativity and selfefficacy

$\mathrm{H}_{0}: \rho=0$ (There is no relationship between creativity and selfefficacy of students based on the FD and FI cognitive styles).

$\mathrm{H}_{1}: \rho \neq 0$, (There is a relationship between creativity and selfefficacy of students based on the FD and FI cognitive styles).

\section{RESULTS AND DISCUSSION}

The data obtained and analysed in this study included the score of creativity tests and self-efficacy data of F D and FI students. Based on the data, normalised gain (N-Gain) of the students' creativity and the self-efficacy data in the experimental and the control class were calculated. Before the 
similarity test, normality and homogeneity were tested for the creativity and self-efficacy data of both students in the experimental and control group. Besides, the N-Gain differences test for each data, both creativity and self-efficacy of FD and FI students was performed. The following is a statistical hypothesis of creativity and self-efficacy data along with a table showing the results of the $\mathrm{N}$-Gain differences test for each data.

\section{Hypothesis 1:}

The following is a statistical hypothesis to observe FD students' creativity.

$\mathrm{H}_{0}: \mu_{1}=\mu_{2}$ (the creativity of the FD students in the

experimental group is the same as the control group)

$\mathrm{H}_{1}: \mu_{1}>\mu_{2}$ (the creativity of the FD students in the experimental group is better than the control group)

The following is the data on the results of the N-Gain difference test in the FD students' creativity.

Table 1. Results on the N-Gain difference test of the creativity of FD students

\begin{tabular}{|c|c|c|c|c|}
\hline \multicolumn{3}{|c|}{ T-test for Similarity } & \multirow[b]{2}{*}{ Annotation } & \multirow[b]{2}{*}{ Conclusion } \\
\hline $\mathrm{T}$ & $d f$ & $\begin{array}{l}\text { Sig. (2- } \\
\text { Tailed) }\end{array}$ & & \\
\hline 3.414 & 28 & 0.002 & $\mathrm{H}_{0}$ rejected & Increase \\
\hline
\end{tabular}

Based on the test results of the N-Gain difference test of the FD students' creativity in Table 1 , the sig. (2-tailed) $=$ 0.002 , for 0.002 is less than 0.05 then $\mathrm{H} 0$ is rejected. Based on the results, it can be concluded that there is an increase in the creativity of FD students who were taught with the PBL model than students who were taught with conventional models.

The following is the hypothesis to observe FI students' creativity.

$\mathrm{H}_{0}: \quad \mu_{1}=\mu_{2} \quad$ (the creativity of the FI students of the experimental group is the same as the control group)

$\mathrm{H}_{1}: \mu_{1}>\mu_{2}$ (the creativity of FI students in the experimental group is better than the control group)

Table 2. Results on the N-Gain difference value of FI students' creativity

\begin{tabular}{ccccc}
\hline \multicolumn{2}{c}{ T-test for Similarity } & Annotation & Conclusion \\
\hline \multirow{2}{*}{$\mathrm{t}$} & $D f$ & $\begin{array}{l}\text { Sig. (2- } \\
\text { Tailed) }\end{array}$ & An & \\
\hline 3.920 & 28 & 0.001 & Ho rejected & Increase \\
\hline
\end{tabular}

Table 2 shows a significant level of N-Gain data creativity of the FI students is 0.001 because 0.001 is less than 0.05 , then $\mathrm{H}_{0}$ is rejected. Based on the results, it can be concluded that there is an increase in the creativity of FI students who were taught with the PBL model than students who were taught with conventional models.

\section{Hypothesis 2:}

The statistical hypothesis to discover the self-efficacy of FD students is as follows:

$\mathrm{H}_{0}: \quad \mu_{1}=\mu_{2}$ (self-efficacy of FD students in the experimental group is the same as in the control group)

$\mathrm{H}_{1}: \quad \mu_{1}>\mu_{2}$ (the self-efficacy of the FD students in the experimental group is better than the control group)

Table 3. Results on the N-Gain difference value of FD students' self-efficacy and creativity

\begin{tabular}{|c|c|c|c|c|}
\hline \multicolumn{3}{|c|}{ T-test for Similarity } & \multirow[b]{2}{*}{ Annotation } & \multirow[b]{2}{*}{ Conclusion } \\
\hline $\mathrm{t}$ & $d f$ & $\begin{array}{l}\text { Sig. (2- } \\
\text { Tailed) }\end{array}$ & & \\
\hline 3.805 & 28 & 0.001 & $\mathrm{H}_{0}$ rejected & Increase \\
\hline
\end{tabular}

The test results of the N-Gain difference value of $\mathrm{FD}$ students' self-efficacy in Table 3 shows that the level of sig. (2 tailed) $=0.001$ which means 0.001 is less than 0.05 then $\mathrm{H} 0$ is rejected. Based on the results, it can be concluded that there is an increase in the self-efficacy of FD students who were taught with the PBL model than students who were taught with conventional models.

Whereas the statistical hypothesis to discover the selfefficacy of students with FI cognitive style is as follows.

$\mathrm{H}_{0}: \mu_{1}=\mu_{2}$ (self-efficacy of FI students in the experimental group is the same as the control group)

$\mathrm{H}_{1}: \mu_{1}>\mu_{2}$ (self-efficacy of FI students in the experimental group is better than the control group)

Table 4. Results on the N-Gain difference value of FI students' self-efficacy and creativity

\begin{tabular}{ccccc}
\hline \multicolumn{3}{c}{ T-test for Similarity } & Annotation & Conclusion \\
\cline { 1 - 1 } & $d f$ & $\begin{array}{c}\text { Sig. (2- } \\
\text { Tailed) }\end{array}$ & An & \\
\hline 2.648 & 28 & 0.013 & $\mathrm{H}_{0}$ rejected & Increase \\
\hline
\end{tabular}

Table 4 above shows that the level of sig. $(2-$ tailed $)=$ 0.013 , for 0.013 is less than 0.05 then $\mathrm{H} 0$ is rejected. Based on the results, it can be concluded that there is an increase in self-efficacy of FI students who were taught with the PBL model than students who were taught with conventional models.

\section{Hypothesis 3:}

The following is a statistical hypothesis to show the relationship between creativity and self-efficacy in FD and FI students.

$\mathrm{H}_{0}: \mu_{1}=\mu_{2}$ (There is no relationship between students' creativity and self-efficacy in terms of $\mathrm{FD}$ and $\mathrm{FI}$ cognitive styles)

$\mathrm{H}_{1}: \mu_{i}>\mu_{2}$ (There is a relationship between creativity and self-efficacy of students in terms of $\mathrm{FD}$ and $\mathrm{FI}$ cognitive style)

The results of the correlation test between creativity and selfefficacy data of FD students are as follows: 
Table 5. Correlation test result of creativity and self-efficacy of FD students

\begin{tabular}{llrr}
\hline & & Creativity & \multicolumn{1}{r}{ Self-Efficacy } \\
\hline \multirow{3}{*}{ Creativity } & $\begin{array}{l}\text { Pearson } \\
\text { Correlation }\end{array}$ & 1 & $0.910^{* *}$ \\
\cline { 2 - 4 } & Sig. (2-tailed) & & 0.000 \\
\cline { 2 - 4 } Self-Efficacy & $\mathrm{N}$ & 30 & 30 \\
\hline & $\begin{array}{l}\text { Pearson } \\
\text { Correlation }\end{array}$ & $0.910^{* *}$ & 1 \\
\cline { 2 - 4 } & Sig. (2-tailed) & 0.000 & 30 \\
\cline { 2 - 4 } & $\mathrm{N}$ & 30 & 30 \\
\hline
\end{tabular}

Table 5 shows the correlation between creativity and selfefficacy of FD students taught by PBL learning models. The results of the correlation test show that the level of sig. (2tailed) is 0.000 , meaning that the significance level is less than 0.05 , and the correlation coefficient between creativity and self-efficacy is 0.910 . This result suggests that HO is rejected and the interpretation of the correlation value is very high, so it can be concluded that there is a significant relationship between creativity and self-efficacy of FD students. The results of the correlation test between creativity and self-efficacy of FI students are shown in table 6.

Table6. The correlation test result of creativity and selfefficacy of FI students

\begin{tabular}{llrr}
\hline & & Creativity & Self-Efficacy \\
\hline \multirow{3}{*}{ Creativity } & $\begin{array}{l}\text { Pearson } \\
\text { Correlation }\end{array}$ & 1 & $0.897^{* *}$ \\
\cline { 2 - 4 } & Sig. (2-tailed) & & 0.000 \\
\cline { 2 - 4 } & $\mathrm{N}$ & 30 & 30 \\
\hline \multirow{3}{*}{ Self-Efficacy } & $\begin{array}{l}\text { Pearson } \\
\text { Correlation }\end{array}$ & $0.897^{* *}$ & 1 \\
\cline { 2 - 4 } & Sig. (2-tailed) & 0.000 & \\
\cline { 2 - 4 } & $\mathrm{N}$ & 30 & 30 \\
\hline
\end{tabular}

The results in Table 6 show that Sig. (2-tiled) is 0.000 , which is less than 0.05 and the correlation coefficient is 0.897 . These results mean that $\mathrm{H} 0$ is received and the interpretation of the correlation value is very high, so it can be concluded that there is a significant relationship between creativity and self-efficacy of FI students.

The research results reveal that the FD and FI students who were given treatment with PBL model have better creativity and self-efficacy than the students who were not given the treatment. Based on the research results, it can be concluded that the PBL model can increase student creativity. The PBL is one of the learning models that can help students to develop their creativity because learning with PBL models requires students to think steps and ideas that will be used to solve a given problem (Johar \& Hanum, 2016).

Moreover, PBL is also a learning model that can improve students' self-efficacy. The PBL is learning where students work on authentic problems to compile their knowledge, develop inquiry and thinking at a high level, and develop selfconfidence (Johar \& Hanum, 2016).

Learning with the PBL model is not only fosters individual creativity and self-efficacy but also can help students to work together in groups when solving a problem. The PBL model requires students to work together in expressing ideas that are owned by each group member. The results of student group work in solving the given problem can be seen in the following pictures.
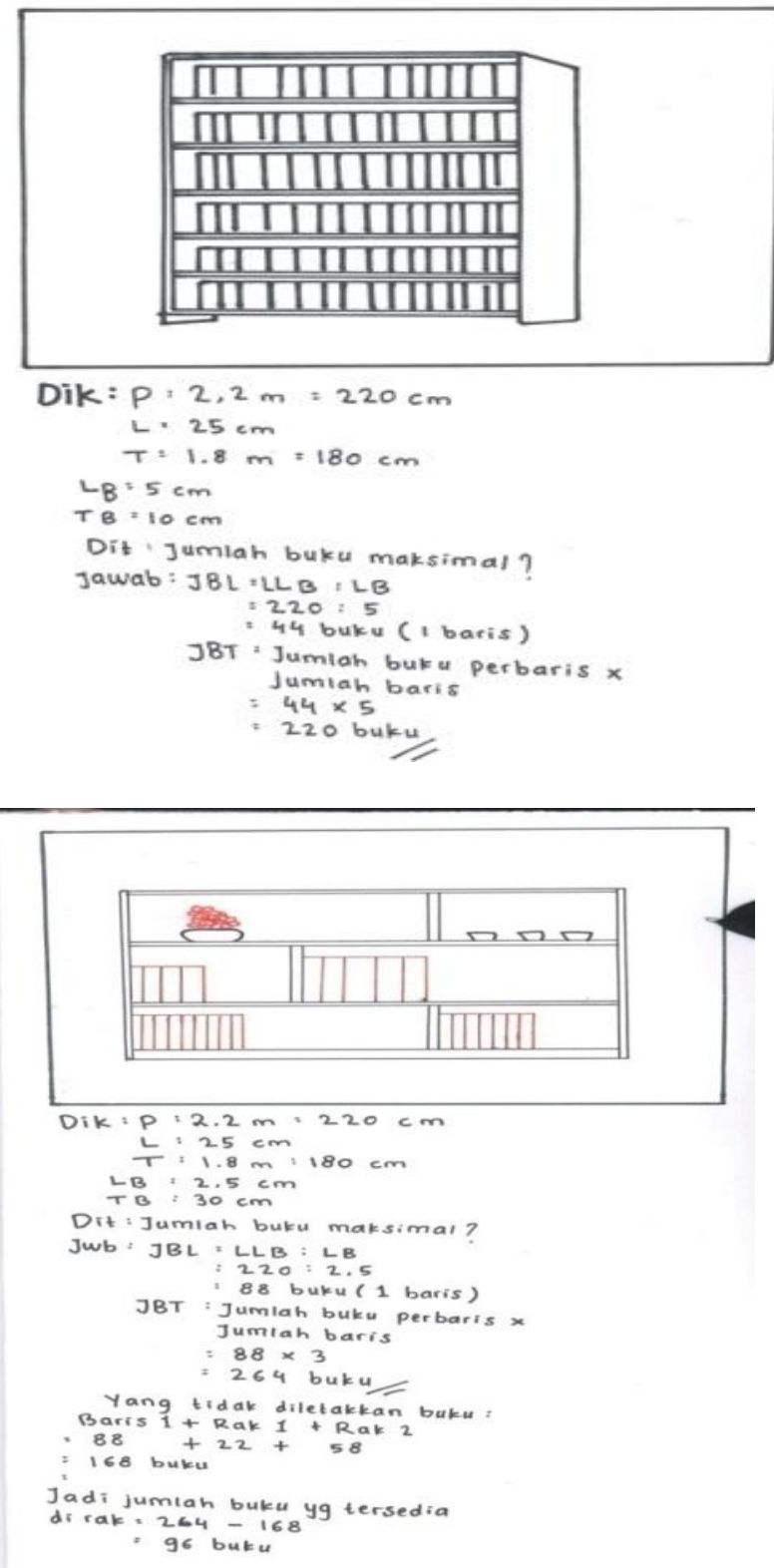

Figure 1. Student's Answer 


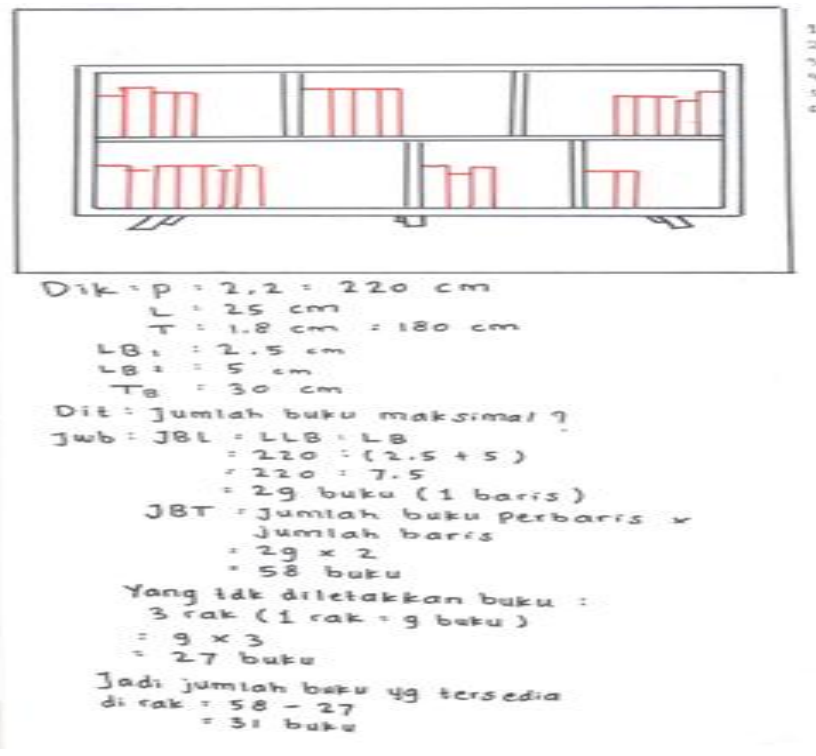

Figure 2. Student's answer

Figure 1 and 2 show the results of students' work in solving an open problem related to a polyhedron. Based on the pictures, it can be seen that from an open problem, students could find a variety of solutions to answer the problem. It shows that the PBL model can help students to find confidence in answering a problem, so the creativity from each student could be discussed with other peers.

Based on the data, it can be found that there is a significant relationship between creativity and self-efficacy both in FD and FI students who were taught with PBL models. This is in line with the results of research by Kisti and Fardana (2012), which showed that students who have good creativity also have good self-efficacy. It means that students who solve mathematical problems using their creativity will be more confident towards their answers.

Self-efficacy is a person's self-confidence to manage and implement a way to solve a problem that is found (Bandura, 1997). However, creativity is a person's ability to process and find a way to solve problems (Agkul \& Kahveci, 2016). Students will have good self-efficacy in solving a problem if the problem is solved by using their creativity. The FD and FI students have good self-efficacy and creativity in determining a way to solve a given mathematical problem. Students who have good self-efficacy will also have good creativity in solving mathematical problems since a strong self-efficacy will bring up new creative ideas in solving the problems.

\section{CONCLUSION}

The increase of creativity and self-efficacy of FD students who were taught with the PBL model is better than students who were taught with conventional methods. It is because students who learnt with the PBL model had the opportunity to express their creative ideas in solving mathematical problems. The increase of creativity and self-efficacy of FI students who were taught with the PBL model is better than students who were taught with conventional methods. It is because the PBL model required students to solve the problem by themselves, so students used their creativity and gained more confidence in solving mathematics problems. Furthermore, there is a significant relationship between creativity and self-efficacy of $\mathrm{F}$ $\mathrm{D}$ and FI students.

\section{ACKNOWLEDGEMENTS}

The authors would like to thank the lecturers for their support and guidance so far, especially Mr Saminan and Mr Zainal Abidin as the supervisor, as well as teachers and students of Banda Aceh MTsN Model for their participation in this research.

\section{REFERENCES}

Akgul, S. \& Kahveci, N. G. (2016), A Study on the Development of a Mathematics Creativity Scale. Eurasian Journal of Educational Research, Issue. 6(2) :57-76

Anggara, F. Yusuf, A. M. \& Marjohan. (2016). Efektivitas Layanan Bimbingan Kelompok dengan Modeling dalam Meningkatkan Efikasi Diri Siswa dalam Menghadapi Ujian. Konselor. 5(1): 1412-9760

Arikunto. (2010). Penelitian Tindakan Kelas. Jakarta: Bumi Aksara

Asri, I \& Warsito, B. (2015). Motivasi Berprestasi, Gaya Belajar, Dan Kemampuan Memanfaatkan Sumber Belajar Kontribusinya Terhadap Kreativitas Mahasiswa D2. Teknodika. 13 (1). 5-19

Bandura, A. (1997) Self-efficacy: The Exercise of Control. New York: W.H. Freeman.

Caprara, G., V. Vecchione, M., Alessandri, G., Gerbino, M \& Barbaranelli, C (2011). The Contribution of Personality Traits and Self-efficacy Beliefs to Academic Achievement:A Longitudinal Study. British Journal of Educational Psychology. 81 (2), 78-96

Creswell, J.W. (2013). Research Design Pendekatan Kualitatif, Kuantitatif, dan Mixed. Yogyakarta: Pustaka Belajar

Johar, R\& Hanum, L. (2016). Teaching and Learning Strategy. Yogyakarta: Deepublish

Kisti, H. H. \& Fardana, N.A., Hubungan antara Self Efficacy dan Kreativitas pada Siswa SMK. Jurnal Psikologi Klinis dan Kesehatan Mental. 1 (2). 52-58

Noer, S. H. (2011), Kemampuan Berfikir Kreatif Matematis dan Pembelajaran Matematika Berbasis Masalah OpenEnded. Jurnal Pendidikan Matematika. 5(1). 104-111

Sembiring, R, K. Hadi, S.\& Dolk, M. (2008). Reforming mathematics learning in Indonesian classrooms through RME, ZDM Mathematics Education. 40 (1), 927-939.

Slavin, R.E. (2008). Education Psychology: Theory and Practice. Translated by Marianto Samosir. Jakarta : Indeks. 